The proposals database also allowed Divisions Chairs to review all submissions to their Division in each of the four categories (paper, panel, poster, chair). And a special Chair's web site provided detailed instructions and sample materials on all aspects of the Chair's responsibilities. The Chair's database and web site will be redesigned next year to incorporate suggestions made by the current chairs.

Among the items the APSA Committee on the Annual Meeting will discuss at its April 24 meeting are the logistics of central processing, the organization of the Meeting, the definition of Program Divisions, the workload of the Program Committee, the increasing number of proposals (up $40 \%$ this year alone), satisfaction of members, and Meeting site selection. The Committee, chaired by Mary F. Katzenstein, will report back to the Council in time for its September 2 meeting.

The Annual Meeting Committee encourages responses from members on any of the topics above. Please address your comments to Mary Katzenstein at meeting@apsanet.org.

\section{Mark Lichbach Renewed As APSR Book Review Editor}

Ada W. Finifter, Editor of the American Political Science Review, has named Mark Lichbach of the University of Colorado for an addi-

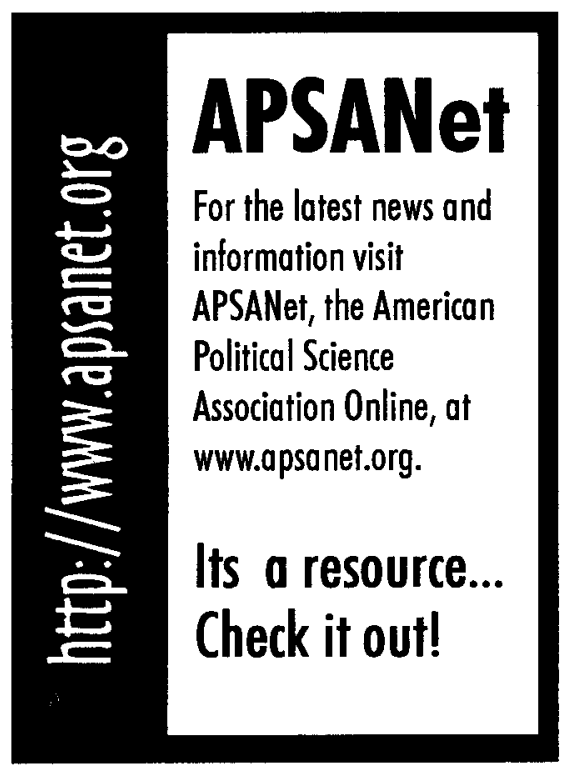

tional three-year term as Editor of the Book Review, beginning in the fall of 1998. APSA and Colorado concluded an agreement for the extension which entails a generous contribution from the university in support of the Book Review.

Originally named by former $A P S R$ editor Bingham Powell and extended by Finifter, Lichbach is in his fourth year as Book Review Editor.

"The Book Review provides the most comprehensive, extensive book reviews in the discipline. Mark Lichbach does an outstanding job intellectually and administratively. I am grateful to him for his willingness to continue to serve, and to Ada Finifter and President Kent Jennings for making the necessary arrangements," said Executive Director Catherine Rudder. "Our profession owes Mark and the University of Colorado a great debt of gratitude for their important contribution to the scholarly life of political science."

\section{Past Issues of $A P S R$ Now Available Through JSTOR}

\section{Theresa Gubicza, APSA}

The American Political Science Association signed an agreement with JSTOR (short for Journal Storage) in 1996 has made the complete archive of the American Political Science Review, beginning in 1906, and the Proceedings of the American Political Science Association, 1903-1914, available through JSTOR's online database. The JSTOR database (http://www.jstor.org) provides electronic access to the backfiles of a number of core scholarly journals in the humanities, social sciences and sciences. APSA entered the agreement after considerable review by both the Publications Committee and the Council. Since signing the JSTOR agreement, APSA has continually informed the regional political science associations about JSTOR's progress and encouraged wide participation by political science journals. A full list of all the journals currently participating in JSTOR is included here.

\section{What is JSTOR?}

JSTOR, a not-for-profit organization headquartered in New York City, was established to improve access to publications for the scholarly community using recent advances in information technology. The pilot phase of JSTOR, funded by a 1994 grant from the Mellon Foundation, gave students and faculty at seven test libraries access to the full archives of five economics and five history journals via the World Wide Web. By November 1997, JSTOR provided access to 32 journals in 12 disciplines and counted more than 200 college and university libraries among its participants.

Originally an initiative to solve library space and budget problems, JSTOR now strives to meet the needs of both scholars and libraries. Participating in JSTOR allows libraries to assemble and expand their collections and increase access to the journals while centralizing storage and delivery of those journals. JSTOR relieves the libraries of preservation and archiving duties while providing access to a number of journals unavailable in any other form. The database contains a thorough and accurate publication record for each journal included, giving the academic community access to full runs of important journal literature, within and across disciplines. The database is accessible 24 hours a day to students and faculty at participating institutions from any networked location, including offices and dorms; journals are never "out," and there are no missing pages or articles as there sometimes are in the stack copies of journals.

Since JSTOR focuses on preserving the archives of scholarly journals, current issues are not available in the database. Most scholarly journals appear on JSTOR three to five years after publication. Currently, JSTOR provides access to the 1906-1994, volumes of $A P S R$ and the full run of The Proceedings of the American Political Science Association, 1903-1914. A complete volume of $A P S R$ is added every year with a three year "moving wall:" in 1998, the 1995 volume will be available; in 1999, the 1996 volume will be available and so on. 


\section{Using JSTOR}

The JSTOR database contains three types of files: high-resolution images that provide a faithful replication of the original page; text files that facilitate full-text searching; and electronic table of contents files that provide the necessary organization for browsing and for accurate displaying of search results. JSTOR's search engine allows users to browse and search individual journals, or perform cross-disciplinary searches of multiple journals in multiple disciplines. Users can search the full text of materials or search by topic, author or key words. With JSTOR, research and literature that have been difficult to locate and retrieve are now easily accessible.

The image of the article appearing in JSTOR is a scanned image of the original journal. Scanning enables JSTOR to provide an exact replica of the original article both on screen and in print. Due to the scanning, it is not possible to cut and paste text from a JSTOR article. However, full articles can be printed from any desktop computer. Printing articles from JSTOR provides higher quality and more legible copies of the journals' pages than photocopying the original journal pages, many of which have yellowed over time. Since JSTOR uses high-resolution images to store and display replications of journal pages, it is not possible to print out articles simply by using the "Print" button in a web browser. Articles can be printed using one of three methods for printing from JSTOR:

1. High resolution copies of entire articles can be printed with a standard printer using JPRINT, the JSTOR print helper application. JPRINT groups the individual page images so that articles can be printed in their entirety, not just one page at a time. Versions of JPRINT for several operating systems are currently available. Users can download JPRINT and obtain step-by-step instructions for downloading, installation and configuration from the JSTOR web site.

2. Users can print portable document format (pdf) versions of JS-

\section{Participating Journals in JSTOR}

\section{ECONOMICS}

American Economic Review*

Econometrica*

Journal of Applied Econometrics

Journal of Economic Literature

The Journal of Economic

Perspectives*

Journal of Industrial Economics

Journal of Political Economy*

The Quarterly Journal of

Economics*

The Review of Economics and Statistics*

The Economic Journal

\section{PHILOSOPHY}

Journal of Philosophy*

Mind

Nous

Philosophical Review

Philosophy and Phenomenological

Research

Philosophical Perspectives

\section{MATHEMATICS}

Annals of Mathematics*

Journal of the American

Mathematical Society

Mathematics of Computation*

Proceedings of the American

Mathematical Society ${ }^{*}$

SIAM Journal on Applied

Mathematics

SIAM Journal on Numerical

Analysis

SIAM Review*

Transactions of The American

Mathematical Society

\section{POLITICAL SCIENCE}

American Journal of Political

Science

American Political Science Review*

Political Science Quarterly

The Journal of Politics

World Politics

Proceedings of the American

Political Science Association*

FINANCE

Journal of Money, Credit and Banking*
POPULATION/DEMOGRAPHY

Demography

Family Planning Perspectives

International Family Planning

Perspectives

Population and Development Review*

Population: An English Selection

Population Index

Population Studies

Studies in Family Planning*

\section{HISTORY}

The American Historical Review* Journal of American History ${ }^{\star}$ Journal of Economic History The Journal of Modern History ${ }^{*}$

Renaissance Quarterly*

Speculum

The Journal of Military History ${ }^{\star}$

William and Mary Quarterly*

Studies in the Renaissance*

\section{SOCIOLOGY}

American Sociological Review

Annual Review of Sociology

Contemporary Sociology: A Journal of

Reviews

Journal of Health and Social Behavior

Sociology of Education

Social Psychology Quarterly

\section{ECOLOGY}

Annual Review of Ecology and

Systematics

Ecological Applications*

Ecological Monographs*

Ecology ${ }^{*}$

\section{ASIAN STUDIES}

Journal of Asian Studies*

The China Journal

IGHER EDUCATION

The Journal of Higher Educatio*

\section{ANTHROPOLOGY}

Annual Review of Anthropology

Anthropology Today

The Journal of the Royal

Anthropological Institute/Man

Proceedings of the Royal

Anthropological Institute
TOR articles using Adobe Acrobat reader which can be freely downloaded from the Web (http:// www.adobe.com/acrobat). Selecting the Adobe Acrobat Printing option will activate the Acrobat Reader. The JSTOR article will be displayed within Acrobat Reader and printed using Adobe menu commands. 


\section{The American Political Science Association EDWARD ARTINIAN MEMORIAL FUND}

an endowment fund for promoting scholarly publishing

We would like to thank the following donors for their generous contributions to the Artinian Memorial Fund.

Herbert E. Alexander
Asher Arian
Patricia Artinian
Samuel H. Barnes
Walter E. Beach
Brenda W. Carter
Russell J. Dalton
Nancy Davidson
Alex N. Dragnich
Cynthia Enloe
James W. Fesler
Charles D. Hadley
Roger Hamburg
Martin O. Heisler
Paul S. Herrnson
William E. Hudson
Malcom E. Jewell
Ruth S. Jones \&
Warren E. Miller
Herbert Kaufman
Donald F. Kett
Anthony King
Elaine S. Levine
Jeremy R.T. Lewis
Robert C. Lieberman

Lyceum Books, Inc. Andrew S. McFarland

Clyde D. Mckee, Jr.

Eugene Meehan

Richard L. Merritt Bruce Miroff

David R. Morgan

Stuart S. Nagel

Thomas E. Patterson

Jack W. Peltason

Gerald M. Pomper

Edward B. Portis

Paul Rejai

Bert A. Rockman

Bernard H. Ross

Catherine E. Rudder

Byron E. Shafer

Henry B. Sirgo

Harold W. Stanley

Judith H. Stiehm

Kenneth D. Wald

Herbert Waltzer

Marvin G. Weinbaum

Marcia Lynn Whicker

The American Political Science Association created the Edward Artinian Memorial Fund in 1997 to honor the memory of Edward Artinian, founder and president of Chatham House Publishers. The Artinian Memorial is an endowment fund intended to support scholarly publishing in all fields of political science.

Contributions in the form of a check should be made out to "APSA-Artinian Fund," and sent to: APSA-Artinian Fund, 1527 New Hampshire Ave., NW, Washington, DC 20036. 
3. Users can retrieve PostScript versions of JSTOR articles, an option most useful for UNIX workstations or Linux PCs for which JSTOR has not provided a print helper application. In order to print the PostScript file, you must be able to use an operating system command.

Currently, only academic libraries and research institutions can participate in JSTOR. However, APSA and other scholarly associations are working with JSTOR and other providers as they explore the possibility of individual access journal content All students and faculty at participating institutions have access to the JSTOR collection. To find out if your institution participates, visit the JSTOR web site (http://www.jstor.org) to view the complete list of institutions.

\section{Participating Journals}

JSTOR has secured the participation of 64 journals in 12 fields, half of which are already accessible By the year 2000 , more than 100 journals in 15 fields will be available on JSTOR's database. Those journals are marked with an asterisk. Journal backfiles are added regularly. Visit the web site for the most current list of journal content available.

\section{MacManus Leads APSA-Law Schools Workshop on Urban Strategies}

Under the auspices of APSA and the Organized Section on Urban Politics, Susan MacManus of University of South Florida, organized political science participation in a daylong workshop entitled "New Strategies for Inner Cities: Academics, Professionals and Communities in Partnership." The January 7 program was jointly sponsored by APSA and the Association of American Law Schools and held in conjunction with the 1998 Annual Meeting of AALS in San Francisco.

This occasion marked the first formally co-sponsored event by the two organizations and represented an effort to foster collaboration between social scientists and legal scholars. Attendance exceeded 300 , and was deemed highly successful by APSA and AALS Executive Directors Catherine Rudder and Carl Monk. "The workshop stemmed from a year's worth of planning and necessitated considerable give-and-take between the two organizations. Our efforts, skillfully spearheaded by Susan MacManus with assistance from APSA staffer Theresa Gubicza, were amply rewarded, “ Rudder observed.

"We learned lessons about interdisciplinary and interorganizational collaboration that we will be able to apply to other joint projects of this sort. In the workshop itself, participants were exposed to the need to reach beyond our individual departments and schools, in order to take advantage of the entire intellectual resources of an institution," said Rudder. "I hope that this workshop will have instigated a desire for scholars from law schools and political science departments to work together."

The central question addressed during the conference was, "how can the talent, energy and knowledge of the academy be unleashed in service of the community in which it exists?" In the morning session three projects-on mapping the effects of concentrated poverty, cleaning up and preventing pollution, and stimulating inner city retail development-were discussed by some of

\section{Updated Professional Ethics Guide Available Online}

The newly-revised Guide to Professional Ethics in Political Science is now available to members online at htp://www.apsanet.org. While no major changes have been made, new language has been added to help political scientists protect themselves from age and sex discrimination and to clarify procedures for individual grievances. The revised ethics guide will soon also be available in booklet form from the APSA.

the participating professors, students, and community members. The presentations were followed by observations from a number of scholars, including Susan Clarke of the University of Colorado, Carlos $\mathrm{Mu}$ noz, Jr. of the University of California, Berkeley, and Helen M. Ingram of the University of California, Irvine.

The afternoon featured a series of concurrent workshops, co-lead by political scientists Nikki Van Hightower, Texas A\&M; Kenneth Wong, University of Chicago; Cynthia Farrar, Yale University; Bruce Cain and Charles P. Henry, University of California, Berkeley; Paula D. McClain, University of Virginia; Michael B. Preston, University of Southern California; Evan McKenzie, University of Illinois, Chicago; Richard R. DeLeon and Brian Murphy, San Francisco State University; and Susan Clarke who also spoke in the morning session.

APSA has a long history of interorganizational cooperation, most notably with the American Historical Association, which copublishes The Scholar Saver and which cosponsored Project ' 87 and the Bill of Rights Education Collaborative. Currently, the American Federation of Teachers, APSA, and the Center for Civic Education are working together on fostering civic education in the new democracies of Eurasia and Eastern Europe. APSA has also initiated interdisciplinary membership arrangements with the American Sociological Association, the American Society of International Law, and AHA.

In addition, APSA is an active member of such multidisciplinary groups as the Consortium of Social Science Associations, the National Humanities Alliance, the American Association for the Advancement of Science, the National Coordinating Committee for the Promotion of History, and the American Council of Learned Societies. Internationally, APSA is a founding member of the International Political Science Association, and former APSA President Theodore Lowi of Cornell University currently serves as its President. 